\title{
ВПЛИВ МІКОРИЗНОГО ГРИБА TUBER MELANOSPORUM НА БIOРIЗНОМАНITTЯ МІКРОМІЦЕТІВ РИЗОСФЕРИ ТА РІСТ І ПРОДУКТИВНІСТЬ ФУНДУКА
}

\begin{abstract}
Наявність мікоризи є чинником ефективного процесу депонування вуглецю в екосистемі. Різні способи мікоризації сприяють ефективному росту та продуктивності рослин. Вивчено вплив Tuber melanosporum IMB F-100106 у складі препарату "Міковітал" на ріст, розвиток та продуктивність фундука сорту 'Шедевр'. Досліджено вплив різних способів внесення мікоризного препарату на ріст та розвиток фундука: замочування коренів, краплинного зрошення та підживлення. Зафіксовано, що діаметр кореневої шийки зріс на 10,2 \%, кількість основних коренів збільшилась на 12,2 \% та довжина кореневої системи - на 13,9 \%. Відзначено також зростання загальної кількості листків на 14,0 \%, довжини річного приросту - на $14,4 \%$ та висоти саджанців - на 12,9\%. Кореневе підживлення 2-5 \%-ми розчинами препарату забезпечило підвищення рівнів урожайності фундука до 21,7-22,4 ц/га 3 отриманням прибавки урожаю на 10,2-13,7 \%. Важливими показниками для горіхоплідних рослин $є$ хімічний склад плодів та їх дегустаційне оцінювання. Кореневе підживлення 2-5 \%-м розчином препарату забезпечило зростання в них вмісту жиру на 1,5-2,7 \%, а також призвело до збільшення виходу ядра на 6,0-6,9 \%. Дегустаційна оцінка плодів підвищилась на 0,3-0,4 бали. Здійснено мікологічний аналіз 150 зразків грунту ризосфери фундука та грунту цілинних земель. Виділено 475 ізолятів мікроміцетів, що належать до 124 видів мікроскопічних грибів. Наведено 48 видів мікроскопічних грибів різних таксономічних груп, які найчастіше траплялись у досліджуваних грунтах. Встановлено, що мікофлора ризосфери мікоризованого та немікоризованого фундука істотно відрізняється за видовим складом. Індекси видового різноманіття мікроміцетів свідчать, що найрізноманітніший видовий склад мікобіоти характерний для ризосфери мікоризованого фундука. Характерною особливістю мікроміцетного складу ризосфери мікоризованого фундука є зменшення чисельності та видового різноманіття патогенів. Проаналізовано місткість екосистеми фундукового саду, тобто здатність створювати умови існування для популяцій різних видів, зокрема мікроміцетів грунту. Визначено роль технології регенеративного землекористування, яку успішно впроваджують в Україні на рівні лісгоспів, малих і середніх фермерських господарств, холдингів. Вона може стати основою Продовольчого Суверенітету нашої країни і дасть змогу Україні розвиватися за своїм унікальним планом: зберегти для прийдешніх поколінь здорове довкілля і годувати населення якісними органічними продуктами харчування.
\end{abstract}

Ключові слова: депонування вуглецю; мікоризація; гетеротрофне живлення рослин; технологія регенеративного землекористування.

\section{Вступ}

Останнє сторіччя характеризується використанням штучних і хімічних речовин та технологій, які спричиняють деградацію земель і забруднення вод унаслідок інтенсивного сільського господарства. Способи землекористування, які людина застосовує вже понад сто років, змінили та зруйнували мікробний склад грунту, знищили зв'язки, які рослини будують між собою у грунті через мікоризу, вплинули на процеси мінералізації та гуміфікації грунтів. Ці зв'язки дають рослинам ростові речовини: гормони росту, макро- та мікроелементи, які синтезують для неї симбіотрофні гриби ендофіти, епіфіти та ризосферні бактерії. За даними ФАО (Продовольча і сільськогосподарська організація Об'єднаних Націй), головним чинником втрати у грунті орга- нічного вуглецю є зміни у землекористуванні. Традиційним і ключовим у науці є положення про автотрофне існування рослинного світу. Тільки з урахуванням симбіотрофного існування рослин, тобто обов'язкової участі грибів та бактерій у життєво важливих процесах рослинних організмів, можна вирішити багато важливих питань, що стосуються їх життєдіяльності.

Одним із способів зниження концентрації вуглекислого газу в атмосфері, у межах виконання положень Конвенції про зміни клімату, ратифікованої урядом України у 1996 р., розглядають збереження та створення екосистем, поліпшення їхньої структури і підвищення продуктивності завдяки переходу на органічні технології в лісовому та сільському господарстві, відновлення порушених земель.

Хоча є грунти, що достатньо охарактеризовані з мі-

\section{Інформація про авторів:}

Оліферчук Вікторія Петрівна, канд. біол. наук, доцент, кафедра екології. Email: victorijaoliferchuk@gmail.com

Федорович Дарія Василівна, д-р біол. наук, професор, відділ молекулярної генетики і біотехнології. Email: fedorovych.d@gmail.com; https://orcid.org/0000-0001-6956-3109

Цитування за ДСтУ: Оліферчук, В. П., Федорович, Д. В. Вплив мікоризного гриба Tuber Melanosporum на біорізноманіття мікроміцетів ризосфери та ріст і продуктивність фундука. Науковий вісник НЛтУ України. 2021, т. 31, № 2. С. 28-34.

Citation APA: Oliferchuk, V. P., \& Fedorovych, D. V. (2021). Influence of tuber melanosporum mycorrhystic mushrooms on the biodiversity rhisosphere micromycetes and growth and productivity of hazelnut. Scientific Bulletin of UNFU, 31(2), $28-34$. https://doi.org/10.36930/40310204 
кологічної точки зору, деяким екосистемам приділено мало уваги, особливо це стосується ролі, яку відіграє мікоризний симбіоз. Враховуючи специфічність господаря й асоційованої мікобіоти, дослідження селективних екосистем $\epsilon$ дуже важливим, оскільки вони можуть визначати біотичні та абіотичні чинники, що мають специфічну дію, взаємовідносини грибів і рослин-господарів та як вони еволюціонують. Мікоризні гриби $є$ основою трофічних взаємозв'язків в екосистемах та основою життя рослин на Землі. Вони є основою регуляції обміну поживними речовинами та відповідальні за покращення властивостей грунту [5, 6, 15, 22]. Основним процесом, який забезпечує депонування вуглецю в екосистемі, є утворення мікоризи. Від складу мікробоценозу грунту - його видової, трофічної, просторової структури - залежить склад газів, що виділяються в атмосферу та їх співвідношення [5, 6, 22].

Види Tuber є ектомікоризними аскоміцетами, які пов'язують різних господарів і утворюють плодові тіла, відомі як трюфелі. Перші докази того, що різні види $T u$ ber мають симбіотичні зв'язки 3 коренями їх господарів було отримано в 60 -х роках $\mathrm{XX}$ ст. [5, 6, 7, 12, 17, 19, 22]. У багатьох країнах трюфелі мають великий попит, завдяки їх специфічному запаху і смаку $[11,13,15,16]$. Тому дослідження цих грибів було зосереджене, в основному, на вдосконаленні технології ї культивування, щоб компенсувати зменшення продукції цього гриба у природних умовах $[7,12,14,16]$. Встановлено, що Tuber melanosporum колонізує корені й утворює типові ектомікоризні структури на коренях багатьох листяних і хвойних порід дерев, зокрема дуба, волоського горіха, фундука, фруктових дерев, а також малини, порічки, чорниці $[3,7,12,15]$. Описано успішне застосування оброблення насіння та замочування коренів саджанців для поліпшення росту та розвитку різних рослин, зокрема дуба $[7,8,10,11,12,16]$. Ми отримали дані успішного застосування інокуляції $T$. melanosporum IMB F100106 для покращення росту і продуктивності бобових та злакових культур [13].

Взаємозв'язки T. melanosporum 3 рослинами, бактеріями та комахами досліджено докладно, проте недостатньо вивчено вплив цього мікоризного гриба на видовий та кількісний склад інших грибів [13].

Актуальність роботи полягає у дослідженні ролі мікоризного симбіозу та створенні загальної мікоризної сітки в екосистемі на прикладі фундукового саду, а також ролі гетеротрофного живлення для життя рослин та депонування вуглецю в екосистемі.

Об'єкт дослідження - мікоризовані та немікоризовані насадження фундука інтенсивного типу навчальнонауково-виробничого відділу Уманського національного університету садівництва.

Предмет дослідження - впровадження методів регенеративного землекористування, основою яких є відновлення симбіотрофних мікоризних взаємодій між мікоризним грибом T. melanosporum та фундуком.

Мета роботи - проаналізувати вплив штаму мікоризного гриба $T$. melanosporum IMB F-100106 на ріст i продуктивність фундука та склад і чисельність мікроміцетів ризосфери.

Для досягнення зазначеної мети визначено такі основні завдання дослідження: дослідити вплив штаму $T$. melanosporum IMB F-100106 на ріст і продуктивність фундука та на видовий і кількісний склад мікофлори його ризосфери; вивчити можливості використання $T$. melanosporum для створення технологій органічного i регенеративного землекористування та збереження генетичної стабільності цього виду.

Наукова новизна отриманих результатів дослідження - вперше мікоризовано фундук препаратом "Miковітал", діючою речовиною якого є активний штам мікоризного гриба T. melanosporum IMB F-100106. Препарат $\epsilon$ першим в Україні мікоризним препаратом, який пройшов державну реєстрацію, отримав сертифікат "Органік Стандарт", штам депоновано в Депозитарії Інституту мікробіології та вірусології ім. Д. К. Заболотного НАН України.

Практична значущість результатів дослідження розроблену технологію впроваджують по всій території України, на різних типах грунтів у різних кліматичних зонах країни та за іiі межами, що сприяє збереженню у грунті органічного вуглецю, збільшенню біорізноманіття мікроміцетів грунту, збереженню вологості грунтів та продуктивності рослин. Основою біотехнології є мікоризація широкого спектра рослин. а саме лісових культур, сільськогосподарських культур, інтродуцентів.

Аналіз останніх досліджень та публікацій. Грунт це поліфункціональна енергетично відкрита саморегульована природна система, яка забезпечує стійкий циклічний характер відтворення життя на Землі [22]. Грунт виникає тільки тоді, коли повноцінно функціонує його 15-20-сантиметровий поверхневий шар, насичений живими організмами, де домінують гриби та бактерії, які відповідають за мінералізацію та гуміфікацію грунтів i мікоризний симбіоз з рослинами.

Симбіотичні зв'язки грибів та мікроорганізмів з рослинами - це основа життя рослин. Тільки за стабільної системи: "корінь-рослини-гриб-бактерія", яка функціонує цілісно і формує загальну мікоризну сітку в екосистемі, відбувається продуктивний ріст і розвиток рослин, що відповідно впливає на всі параметри екосистеми, зокрема на склад та кількість парникових газів, i відповідно на клімат планети. Ще на початку XX ст. відомий японський учений Т. Асаї, досліджуючи рослини, що росли на вулканічному грунті, на великих висотах в горах, на морському узбережжі, на коралових островах та у субтропіках Японії, довів, що рослини є мікотрофними при всіх показниках $\mathrm{pH}$, на всіх типах грунтів та у всіх кліматичних зонах. Цей вид симбіозу ніяк не залежить від зовнішніх чинників, за винятком водних рослин. Це пов'язано із двома причинами: $a$ ) корені водних рослин слабо забезпечені киснем, а гриби аеробні організми; б) мікориза розвивається у найдрібніших коренях, якої у водних рослин немає. Тому водні рослини вважають слабо мікотрофними $[5,6,22]$.

Водночас, чеські вчені А. Клечка та В. Вуколов детально вивчили мікотрофність деревних порід і кущів Центральної Європи [5, 6, 22]. Автори відзначили, що мікотрофність вивчених порід не залежить від типу грунту. Одним з перших авторів, який вивчав мікоризний симбіоз, був А. Франк у XIX ст., який ще тоді визначив цей симбіоз як такий, що ніяк не залежить від умов навколишнього середовища. У 1981 р. І. А. Селіванов у своїй науковій праці прийшов до висновку, що "...мікосимбіотрофність рослин $\epsilon$ правилом, а не винятком". Мікоризні взаємовідносини не є видоспецифічні. Мікоризу однієї і тієї самої рослини можуть утворюва- 
ти різні гриби, а також один і той самий гриб може утворювати мікоризу з різними рослинами $[1,5,6,22]$.

Уже понад столітній досвід вивчення явища симбіотрофності у рослин довів, що мікориза - це одне 3 фундаментальних явищ природи, яке притаманне наземним рослинам з моменту їх створення і $\epsilon$ найдревнішою формою симбіозу рослин із грибами та бактеріями. Мікотрофними сьогодні вважають 98 \% видів рослин на планеті. У мікоризній симбіотрофії міцелій гриба колонізує корені чи інші органи рослини-хазяїна внутрішньо- або зовнішньоклітинно. Знищення цих зв'язків унаслідок господарської діяльності людини призводить до руйнування імунітету рослин, зниження їх продуктивності та якості, і врешті-решт - до загрози Продовольчому Суверенітету цілих країн і регіонів планети.

Вуглець, водень та кисень - основні елементи, які містяться в атмосфері, і організмами, які переводять їх у грунт, є бактерії та гриби. Процес перетворення вуглецевих сполук - основа життя на Землі. В антропогенних екосистемах кругообіг вуглецю $є$ від'ємно декомпенсованим [4]. Між різними резервуарами вуглецю відбувається транспорт неорганічних речовин i цей процес є джерелом вуглеводів для рослин. Ефективний процес фотосинтезу забезпечується достатньою часткою вуглецю, яка становить приблизно 50 \%. Поглинальна здатність кореня рослини збільшується завдяки тому, що гіфи мають ширший радіус та швидкість поширення, ніж кореневі волоски, а також здатні поглинати поживні речовини у низьких концентраціях. Особливо важливе значення має мікориза у покращенні фосфорного живлення [2, 3, 4, 9, 17, 21]. Рослина отримує фосфор у вигляді поліфосфатів через гіфи мікоризних грибів. Саме тому мікоризовані корені поглинають більше вологи і менше страждають від посухи. Мікоризні гриби синтезують антибіотики, гормони росту та інші біологічно активні речовини. Гриби-мікоризоутворювачі впливають на кількість і якість кореневих ексудатів, й у такий спосіб формують мікробне угруповання ризосфери. У зоні мікоризосфери змінюється чисельність та видовий склад бактерій та актиноміцетів у бік їх збільшення, а чисельність фітопатогенів зменшується. Рослини також стають резистентними до вірусних захворювань.

Гриби-мікоризоутворювачі взаємодіють 3 різними групами бактерій, такими як Pseudomonas, Bacillus, Azotobacter. Ендомікоризні гриби бобових стимулюють азотфіксацію ризобій. Цей феномен використовують для підсилення азотфіксації при одночасному обробленні насіння ризобіями і мікоризними грибами. Бактеріï, які сприяють утворенню мікробного симбіозу, називають хеллерами. Вони стимулюють ріст грибів на стадії перед симбіозом, збільшуючи вірогідність контакту коренів з грибами [5, 6, 9, 12, 16, 17, 20, 21, 22].

Технологічна стимуляція процесів так званого "гетеротрофного живлення рослин", завдяки утворенню мікоризного симбіозу, дає змогу замінити інтенсивні системи землеробства органічними й отримати продуктивні рослини. Відтворення потрійного симбіозу у грунті (рослина-гриб-бактерія) - це ефективний та швидкий спосіб підвищення якості врожаїв усіх сільськогосподарських культур, ефективного відновлення лісів, збереження садів, парків, скверів міст та регенерації порушених після видобування корисних копалин земель. Для того, щоб активно розпочати етап регенеративного землеробства в Україні, відновлення родючості грунтів завдяки відновленню грунтової мікрофлори та мікоризації рослин необхідно здійснювати широкі моніторингові дослідження хімічного та мікологічного складу грунтів, і на підставі цих досліджень створювати специфічні технології регенерації для конкретних екосистем.

Матеріали та методи дослідження. Дослідження впливу мікоризації на ріст і розвиток фундука та вплив на склад мікроміцетів його ризосфери здійснювали впродовж протягом 2017-2020 років. Посадили фундук у квітні 2017 року. Насадження інтенсивного типу було створено навчально-науково-виробничим відділом Уманського національного університету садівництва, закладеного кафедрою плодівництва і виноградарства. Ірунтово-кліматична зона - Лісостеп України, густота посадки $3 \times 5$ м (667 кущів/гa). Грунт - чорнозем опідзолений малогумусний важкосуглинковий на лесі. За кислотністю грунт близький до нейтрального, з низьким вмістом гумусу та дуже низьким вмістом нітрогену, 3 підвищеним вмістом фосфору та калію (табл. 1).

Табл. 1. Результати агрохімічного аналізу грунту

\begin{tabular}{|c|c|c|c|c|c|}
\hline \multirow[b]{2}{*}{ Варіант } & \multirow[b]{2}{*}{$\mathrm{pH}$} & \multirow{2}{*}{$\begin{array}{c}\text { Нітроген гід- } \\
\text { ролізований, } \\
\text { за Корнфіл- } \\
\text { дом, мг/кг }\end{array}$} & $\mathrm{P}_{2} \mathrm{O}_{5}$ & $\mathrm{~K}_{2} \mathrm{O}$ & \multirow[b]{2}{*}{$\begin{array}{l}\text { Гумус, за } \\
\text { Тюріним, \% }\end{array}$} \\
\hline & & & \multicolumn{2}{|c|}{$\begin{array}{c}\text { за Чириковим, } \\
\text { мг/кг }\end{array}$} & \\
\hline Орний шар & 6,0 & 64,0 & 101,0 & 119,0 & 3,6 \\
\hline
\end{tabular}

Дослід проводили за температури повітря $9,5^{\circ} \mathrm{C}$, відносної вологості - 75,5 \%. Під час оброблення коренів рослин опадів не було, пряме сонячне проміння на препарат та корені не потрапляло. Площа облікової ділянки $-75 \mathrm{~m}^{2}$, розміщення ділянок систематичне, кількість ділянок - 3. У табл. 2 наведено характеристику метеорологічних чинників у період вегетації.

Табл. 2. Характеристика метеорологічних чинників у період вегетації

\begin{tabular}{|l|c|c|c|c|c|}
\hline \multicolumn{1}{|c|}{$\begin{array}{c}\text { Основний } \\
\text { показник }\end{array}$} & \multicolumn{5}{|c|}{ Місяць } \\
\cline { 2 - 6 } & квітень & травень & червень & липень & серпень \\
\hline $\begin{array}{l}\text { Поточного року } \\
\text { (ередня) }\end{array}$ & 6,1 & 10,6 & 15,4 & 19,6 & 19,5 \\
\hline $\begin{array}{l}\text { Середня багато- } \\
\text { річна }\end{array}$ & 8,0 & 14,1 & 17,1 & 18,3 & 17,7 \\
\hline $\begin{array}{l}\text { Відхилення від } \\
\text { багаторічної }\end{array}$ & $-1,9$ & $-3,5$ & $-1,7$ & 1,3 & 1,8 \\
\hline $\begin{array}{l}\text { Опади, мм } \\
\text { Поточного року } \\
\text { в середньому) }\end{array}$ & 63 & 41 & 50 & 62 & 51 \\
\hline $\begin{array}{l}\text { Середнс багато- } \\
\text { річне }\end{array}$ & 49 & 63 & 87 & 92 & 68 \\
\hline $\begin{array}{l}\text { Відхилення від } \\
\text { багаторічного }\end{array}$ & 14 & -22 & -37 & -30 & -17 \\
\hline
\end{tabular}

Для мікоризації фундука використали препарат "Міковітал", діючою речовиною якого є активний штам мікоризного гриба T. melanosporum IMB F-100106. Як контроль використовували еталонний препарат МайкПро PS 3. Виділення мікроміцетів 3 ризосфери рослин, їх ідентифікацію та статистичне оброблення отриманих результатів здійснювали за стандартними методиками [1].

\section{Результати дослідження та їх обговорення}

Вилив T. melanosporum IMB F-100106 на picm, розвиток і продуктивність фундука сорту 'Шедевр'. Лісовий горіх має важливе соціально-економічне значен- 
ня, оскільки дає змогу не тільки отримати плоди лісового горіха, а й ці самі площі можуть бути використані для продукції отримання плодових тіл трюфеля. Характеристику грунту та умови обробітку описано в розділі "Матеріали і методи".

Замочування перед посадкою коренів саджанців фундука препаратом "Міковітал", створеним на підставі вегетативних клітин і спор $T$. melanosporum IMB F100106 , позитивно вплинуло на ріст і розвиток кореневої системи саджанців фундука (табл. 3). Діаметр кореневої шийки зріс на 10,2\%, кількість основних коренів збільшилась на 12,2 \% та довжина кореневої системи на 13,9\%, відносно контролю (без обробляння препаратом "Міковітал"). Позитивний вплив на кореневу систему був кращим, ніж у разі застосування еталонного продукту МайкПро PS 3.

Табл. 3. Вплив замочування коренів саджанців препаратом на підставі T. melanosporum IMB F-100106 на ріст кореневої системи фундука

\begin{tabular}{|c|c|c|c|}
\hline Варіант досліду & $\begin{array}{c}\text { Діаметр } \\
\text { кореневої } \\
\text { шийки, см }\end{array}$ & $\begin{array}{c}\text { Кількість ос- } \\
\text { новних коре-- } \\
\text { нів, шт. }\end{array}$ & $\begin{array}{c}\text { Довжина ко- } \\
\text { реневої сис- } \\
\text { теми, см }\end{array}$ \\
\hline $\begin{array}{c}\text { Контроль } \\
\text { (без оброблення) }\end{array}$ & $9,8^{ \pm 0,5}$ & $4,9^{ \pm 0,1}$ & $16,5^{ \pm 1,8}$ \\
\hline $\begin{array}{c}\text { Препарат-еталон } \\
\text { МайкПро РS 3 }\end{array}$ & $10,4^{ \pm 0,7}$ & $5,2^{ \pm 0,2}$ & $17,9^{ \pm 1,5}$ \\
\hline $\begin{array}{c}\text { Оброблення } T . \\
\text { melanоsрогиm }\end{array}$ & $10,8^{ \pm 0,8}$ & $5,5^{ \pm 0,4}$ & $18,8^{ \pm 1,6}$ \\
\hline
\end{tabular}

Примітка: *аналіз проведено після 12 місяців вирощування.

Замочування коренів саджанців фундука перед садінням позитивно впливало також на показники росту та розвитку їх надземної частини (табл. 4). Воно привело до зростання загальної кількості листків на 14,0\%, довжини річного приросту - на $14,4 \%$ та висоти саджанців - на 12,9 \%, порівняно із контрольним варіантом. Ростові характеристики надземної частини саджанців фундука були кращі порівняно з еталонним продуктом МайкПро PS 3.

Табл. 4. Вплив замочування коренів фундука препаратом на підставі T. melanosporum IMB F-100106 на ріст і розвиток надземної частини саджанців *

\begin{tabular}{|l|c|c|c|}
\hline Варіант досліду & $\begin{array}{c}\text { Загальна кіль- } \\
\text { кість листків, } \\
\text { шт. }\end{array}$ & $\begin{array}{c}\text { Довжина річно- } \\
\text { го приросту, см }\end{array}$ & $\begin{array}{c}\text { Висота са- } \\
\text { джанців, } \\
\text { см }\end{array}$ \\
\hline $\begin{array}{l}\text { Контроль (без } \\
\text { оброблення) }\end{array}$ & $25,8^{ \pm 2,4}$ & $19,5^{ \pm 1,7}$ & $93,7^{ \pm 2,9}$ \\
\hline $\begin{array}{l}\text { Препарат-еталон } \\
\text { МайкПро РS 3 }\end{array}$ & $28,6^{ \pm 2,1}$ & $21,6^{ \pm 1,5}$ & $102,4^{ \pm 3,2}$ \\
\hline $\begin{array}{l}\text { Оброблення T. } \\
\text { melanosporum }\end{array}$ & $29,4^{ \pm 2,6}$ & $22,3^{ \pm 1,8}$ & $105,8^{ \pm 2,8}$ \\
\hline
\end{tabular}

Примітка: *аналіз проведено після 12 місяців росту.

Табл. 5. Вплив краплинного зрошення посадок фундука препаратом на підставі T. melanosporum IMB F-100106 на урожайність рослин*

\begin{tabular}{|l|c|c|c|c|}
\hline \multicolumn{1}{|c|}{ Варіант досліду } & $\begin{array}{c}\text { Уро- } \\
\text { жайність, } \\
\text { ц/га }\end{array}$ & $\begin{array}{c}\text { Прибав- } \\
\text { ка вро- } \\
\text { жаю, \% }\end{array}$ & $\begin{array}{c}\text { Маса } \\
\text { плода } \\
\text { біддя, г г }\end{array}$ & $\begin{array}{c}\text { Уро- } \\
\text { жайність } \\
\text { одного } \\
\text { куща, кг }\end{array}$ \\
\hline $\begin{array}{l}\text { Контроль (без об- } \\
\text { роблення) }\end{array}$ & $19,7^{ \pm 1,4}$ & - & $2,87^{ \pm 0,8}$ & $10,8^{ \pm 1,8}$ \\
\hline $\begin{array}{l}\text { Препарат-еталон } \\
\text { МайкПро РS 3 }\end{array}$ & $21,3^{ \pm 1,6}$ & $8,1^{ \pm 0,2}$ & $3,15^{ \pm 0,5}$ & $11,5^{ \pm 1,5}$ \\
\hline $\begin{array}{l}\text { Оброблення T. mela- } \\
\text { поsporum }\end{array}$ & $21,7^{ \pm 1,5}$ & $10,2^{ \pm 0,4}$ & $3,19^{ \pm 0,6}$ & $11,7^{ \pm 1,6}$ \\
\hline
\end{tabular}

Примітка: *аналіз проведено після 12 місяців росту.
Досліджено ефективність застосування препарату "Міковітал" для кореневого підживлення через систему краплинного зрошення на наявних посадках фундука. Результати наведено в табл. 5.

Кореневе підживлення 2-5 \%-ми розчинами препарату забезпечило зростання рівнів урожайності фундука до $21,7-22,4$ ц/га 3 отриманням прибавки урожаю на 10,2-13,7 \%, порівняно 3 контрольним варіантом. Урожайність фундука була вища на 1,9-5,2 \% порівняно 3 урожайністю фундука в разі застосування препарату МайкПро PS 3. При цьому відзначено зростання маси одного плода без супліддя на 11,1-12,9 \% та урожайність одного куща на 8,3-13,9 \%, порівняно з контролем.

Важливими показниками горіхоплідних рослин $є$ хімічний склад плодів та їх дегустаційна оцінка. Кореневе підживлення 2-5 \%-м розчином препарату на підставі T. melanosporum IMB F-100106 забезпечило зростання в них вмісту жиру на 1,5-2,7 \%, а також привело до збільшення виходу ядра на 6,0-6,9 \%, порівняно 3 контрольним варіантом. Ці показники були вищі, ніж 3 використанням еталонного препарату МайкПро PS 3 (табл. 6).

Табл. 6. Вплив підживлення препаратом "Міковітал" на підставі T. melanosporum IMB F-100106 на хімічний склад плодів фундука, вихід ядра та їх дегустаційну оцінку

\begin{tabular}{|l|c|c|c|}
\hline \multicolumn{1}{|c|}{ Варіант досліду } & $\begin{array}{c}\text { Вихід яд- } \\
\text { ра, \% }\end{array}$ & $\begin{array}{c}\text { Вміст } \\
\text { жиру, \% }\end{array}$ & $\begin{array}{c}\text { Дегустаційна } \\
\text { оцінка, бал }\end{array}$ \\
\hline Контроль (без оброблення) & $49,3^{ \pm 3,4}$ & $63,8^{ \pm 4,7}$ & $3,8^{ \pm 0,1}$ \\
\hline $\begin{array}{l}\text { Оброблення препаратом- } \\
\text { еталоном МайкПро PS 3 }\end{array}$ & $54,8^{ \pm 3,1}$ & $65,0^{ \pm 4,5}$ & $4,0^{ \pm 0,2}$ \\
\hline $\begin{array}{l}\text { Оброблення T. melanospo- } \\
\text { rum (2 \% розчин препарату) }\end{array}$ & $55,3^{ \pm 3,6}$ & $65,3^{ \pm 4,8}$ & $4,1^{ \pm 0,1}$ \\
\hline $\begin{array}{l}\text { Оброблення T. melanospo- } \\
\text { rum (5 \% розчин препарату) }\end{array}$ & $56,2^{ \pm 3,6}$ & $66,5^{ \pm 4,8}$ & $4,2^{ \pm 0,3}$ \\
\hline
\end{tabular}

Дегустаційна оцінка плодів після оброблення препаратом "Міковітал" підвищилась на 0,3-0,4 бали. Вплив T. melanosporum IMB F-100106 на видовий і кількісний склад мікроміцетів ризосфери фундука сорту "Шедевр"

Важливою характеристикою угруповань мікроміцетів $\epsilon$ чисельність видів, які входять до його складу. Високим рівнем екологічної місткості відзначається агроценоз фундукового саду. Важливою характеристикою саду $є$ місткість його екосистеми, тобто здатність створювати умови існування для популяцій різних видів, зокрема мікроміцетів грунту. Чим більше видів існують у цій екосистемі - тим більша їі місткість. Подібні дослідження проводили автори на однорічних культурах, вивчаючи вплив мікоризації на врожай $[7,8,19,20,21]$, але результатів впливу на зміни мікоценозу грунтів у багаторічних насадженнях не достатньо.

Ми вивчали вплив на біорізноманіття мікроміцетів ризосфери грунту фундука, корені якого були оброблені мікоризним препаратом, у складі якого містились вегетативні клітини штаму $T$. melanosporum IMB F100106. Порівнювали території, які були засаджені немікоризованими саджанцями, та території цілинних земель того самого типу грунту. Проведено мікологічний аналіз 150 зразків грунту ризосфери фундука та грунту цілинних земель поблизу дослідних ділянок насаджень навчально-науково-виробничого відділу Уманського національного університету садівництва. Виділено 475 ізолятів мікроміцетів, що належать до 124 видів мікроскопічних грибів. У таблицю внесено тільки 48 видів мікроскопічних грибів різних таксономічних 
груп, які найчастіше траплялись у досліджуваних грунтах. Встановлено, що загалом комплекс патогенних видів представлений 12 видами мікроміцетів, які переважно виділяли із грунту ризосфери немікоризованого фундука. Так, з ризосфери мікоризованого та немікоризованого фундука було виділено 38 видів грибів (табл. 7). Із ризосфери мікоризованого та немікоризованого фундука виділено тільки 9 спільних видів. Із ризосфери мікоризованого фундука і територій необробленого поля 17 видів. Мікофлора ризосфери мікоризованого та немікоризованого фундука істотно відрізнялась за видовим складом.

Табл. 7. Видовий склад та частота трапляння мікроміцетів грунту досліджених територій

Назва виду

\begin{tabular}{|c|c|c|c|}
\hline Назва виду & Територія цілинних земель & Немікоризований фундук & Мікоризований фундук \\
\hline \multicolumn{4}{|c|}{ Zygomycota, Zygomycetes, Mucorales, Mortierellaceae } \\
\hline Mortierella humilis Linnem. et W. Gams & 0,7 & - & 1,4 \\
\hline Mortierella isabellina Oudem. & 0,7 & 0,7 & 0,7 \\
\hline Mortierella vinacea Dixon-Steward & - & 10,2 & - \\
\hline \multicolumn{4}{|c|}{ Mucorales, Mucoraceae } \\
\hline Mucor globosus Fischer & 3,4 & 0,7 & 1,4 \\
\hline M. hiemalis Wechmer & 2,0 & - & - \\
\hline M. racemosus Fres. & 3,4 & -- & - \\
\hline Mucorsp. & - & 7,0 & 8,1 \\
\hline \multicolumn{4}{|c|}{ Ascomycota, Plectomycetes, Eurotiales, Eurotiaceae } \\
\hline Eurotium amstelodami Mangin & 3,4 & - & 2,0 \\
\hline \multicolumn{4}{|c|}{ Microascales, Microascaceae } \\
\hline Ceratocystis sp. & - & - & 0,7 \\
\hline \multicolumn{4}{|c|}{ Pyrenomycetes, Sordariales, Chaetomiaceae } \\
\hline Chaetomium globosum Kunze: Fr & 7,0 & - & 2,4 \\
\hline \multicolumn{4}{|c|}{ Sphaeropsidales, Sphaerioidaceae } \\
\hline Phoma glomerata $(\mathrm{Cda})$ Wollenw. et Hochapfel & 12,3 & - & - \\
\hline Ph. aliena (Fr.: Fyare) Aa et Boerema & - & 1,4 & - \\
\hline \multicolumn{4}{|c|}{ Hyphomycetes, Agonomycetales, Agonomycetaceae } \\
\hline Mycelia sterilia $($ dark $) 1$ & 2,0 & - & 2,7 \\
\hline Mycelia sterilia (dark) 2 & 1,4 & - & 0,7 \\
\hline Mycelia sterilia (white) 1 & 7,0 & - & 0,7 \\
\hline Mycelia sterilia (white) 2 & 2,0 & - & 0,7 \\
\hline Rhizoctonia solani Künh & - & - & 0,7 \\
\hline \multicolumn{4}{|c|}{ Hyphomycetales, Dematiaceae } \\
\hline Acremonium murorum $(\mathrm{Cda})$ W. Gams & 2,0 & - & 1,4 \\
\hline Alternaria alternata (Fr.: Fyare) von Keissl. & - & 3,4 & - \\
\hline Aureobasidium pullulans (dBy) Arnaud & 1,4 & 2,0 & 10,7 \\
\hline Cladosporium cladosporioides (Fres.) de Vries & 0,7 & - & 3,4 \\
\hline Humicola fuscoatra Traaen & 0,7 & 2,0 & 2,0 \\
\hline H. grisea Traaen & 2,0 & - & 5,4 \\
\hline Oidiodendron griseum Robak & 5,1 & - & - \\
\hline \multicolumn{4}{|l|}{ Moniliaceae } \\
\hline Aspergillus sulphureus Thom & - & - & 3,4 \\
\hline Aspergillus nigerThom & - & - & 6,1 \\
\hline Penicillium chrizogenum Thom & - & - & 0,7 \\
\hline Penicillium decumbens Thom & - & - & 8,2 \\
\hline P. raciborskii Zaleski & - & - & 10,7 \\
\hline P. rubrum Stoll & - & - & 5,4 \\
\hline P. funiculosum Thom & - & 1,4 & - \\
\hline Penicillium sp. & - & 1,4 & - \\
\hline Penicillium claviforme Bainier & - & - & 10,7 \\
\hline Penicillium globozum Lk & - & - & 2,0 \\
\hline P. brevicompactum Dierckx & - & 0,7 & - \\
\hline P. corymbiferum Westl & - & 3,4 & - \\
\hline P. cyclopium Westl & 10,7 & - & 7,0 \\
\hline P. lanosum Westl. & 0.7 & 5,4 & 2,0 \\
\hline P. multicolor Novobr. & - & - & 7,0 \\
\hline Trichothecium roseum (Pers.: Fyare) Lk & - & 0,7 & - \\
\hline Trichoderma atroviride P. Karsten & - & - & 10,7 \\
\hline T. köningii Oudem. & - & 5,4 & 3,4 \\
\hline T. viride Pers.: Fr & 6,1 & - & 1,7 \\
\hline \multicolumn{4}{|c|}{ Tuberculariales, Tuberculariaceae } \\
\hline Fusarium heterosporum Nees & - & 1,4 & - \\
\hline F. javanicum Koord. & - & 10,7 & - \\
\hline F. lateritium Nees Fr & - & 3,4 & 0,7 \\
\hline F. oxysporum (Schlecht.) Snyd. et Hans. & - & 10,7 & - \\
\hline F. solani (Mart.) Sacc & - & 3,4 & - \\
\hline
\end{tabular}

Примітка: жирним шрифтом позначено види мікроскопічних грибів, які потенційно здатні спричиняти захворювання різних рослин; - означає відсутність зазначеного виду в досліджуваному екотопі. 
Результати аналізу подібності видового складу мікобіоти за коефіцієнтом Соренса-Чекановського свідчать, що найбільшу подібність видової структури грибів зафіксовано між екотопом 1 та $3(S=1,78)$, тобто між територією цілинних земель, та ділянкою, де проводили мікоризацію посадкового матеріалу фундука. Найбільшу відмінність за видовим складом мікобіоти виявлено між екотопом 2 та $3(S=1,05 ;)$, ділянкою немікоризованого та мікоризованого фундука. Індекси видової різноманіття мікроміцетів свідчать, що найрізноманітніший видовий склад мікобіоти характерний для екотопу 3 (ризосфера мікоризованого фундука), $(H=3,12)$, що свідчить про позитивний вплив мікоризації, яка забезпечує збільшення біорізноманіття інших видів грибів, й у такий спосіб сприяє ефективному живленню рослин завдяки стимуляції ферментативних процесів у грунті та ефективному надходженню поживних елементів до рослини. Найбільш спрощеним був видовий склад екотопу 2 (немікоризований фундук) $(H=1,17)$. Пояснюють таке явище повільною адаптацією рослини до нових умов середовища після висаджування їх на нових територіях. Отже, мікоризація стимулює процеси приживлення рослин і відновлення мікрофлори ризосфери після перекидання грунтового пласту та втручання у структуру грунту. Коефіцієнт Шенона є досить низьким у всіх варіантах, окрім екотопу 3, що свідчить про процес відновлення та збагачення мікроміцетного складу грунтів на ділянці росту мікоризованого фундука (табл. 8).

Табл. 8. Порівняння видового складу мікроміцетів, виділених з вивчених екотопів

\begin{tabular}{|l|c|c|}
\hline \multicolumn{1}{|c|}{ Вивчений екотоп } & $\begin{array}{c}\text { Коефіцієнт } \\
\text { Шенона }\end{array}$ & $\begin{array}{c}\text { Індекс Сім- } \\
\text { псона (C) }\end{array}$ \\
\hline Територія необробленого поля & 2,23 & 0,217 \\
\hline Немікоризований фундук & 1,17 & 0,229 \\
\hline Мікоризований фундук & 3,12 & 0,205 \\
\hline
\end{tabular}

Результати аналізу особливостей формування мікологічної структури у досліджуваних екотопах свідчать про зростання коефіцієнта Шенона, тобто зростання біорізноманіття мікроміцетів грунту на території, де було висаджено мікоризований фундук. Також зменшувався індекс Сімпсона, у цьому випадку зменшувалося домінування видів, які є потенційними патогенами, а саме видів родів Fusarium, Trichothecium, Phoma, Alternaria, деяких видів роду Penicillium.

\section{Висновок}

Отже, внаслідок проведених експериментів вдалось показати, що від синхронності та потужності процесів мінералізації, гуміфікації та мікоризного потенціалу екосистеми залежить енергетичний потенціал грунту, який проявляється у продуктивності рослин, підвищенні якісних та кількісних показників росту та розвитку фундука.

Наявність мікоризного симбіозу зменшує кількість та видовий склад патогенів грунту, сприяє збільшенню біорізноманіття мікроміцетів ризосфери фундука. Застосування біотехнологій регенерації грунтів на підставі відновлення загальної мікоризної сітки в екосистемі та потрійного симбіозу рослина-гриб-бактерія $є$ перспективним напрямом у фітомеліорації девастованих земель у лісовому та сільському господарстві.

Ці дослідження змінюють також наукову парадигму, яка базується на положенні про автотрофне існування рослинного світу. Дослідження мікоризного симбіозу дасть змогу ще раз акцентувати увагу на вивченні процесів "гетеротрофного живлення" рослин і зробити внесок у процес перемикання світогляду наукового співтовариства на нову систему світогляду і цінностей.

\section{References}

1. Al-Askar, A. A., Rashad, Y. M., Plant Pathol, J., \& Rashad, Y. M. (2010). Arbuscular mycorrhizal fungi: a biocontrol agent against common bean Fusarium root disease, 9(1), 31-38. https://doi.org/10.3923/ppj.2010.31.38

2. Belfiori, B., Riccioni, C., Tempesta, S., et. al. (2012). Comparison of ectomycorrhizal communities in natural and cultivated Tuber melanosporum truffle grounds. FEMS Microbiol Ecol, 81, 547561. https://doi.org/10.1111/j.1574-6941.2012.01379

3. Comandini, O., Contu, M., \& Rinaldi, A. C. (2006). An overview of Cistus ectomycorrhizal fungi, 381-395. https://doi.org/10.1007/s00572-006-0047-8

4. Fassi, B., \& Fontana, A. (1967). Sintesi micorrizica tra Pinus strobus e Tuber maculatum - I., Micorrize e sviluppo dei semenzali nel secondo anno. Allionia, 177-186.

5. Geltcer, F. Iu. (1981). Mikrobiologicheskaia teoriia immuniteta. Zashhita rastenii, 9, 22-24. [In Russian].

6. Geltcer, F. Iu. (1990). Simbioz s mikroorganizmami - osnova zhizni rastenii. Moscow: Izd-vo MSKhA, 134 p. [In Russian].

7. Gioacchini, A., Menotta, M., Bertini, L., et. al. (2005). Solid-phase microextraction gas chromatography/mass spectrometry: a new method for species identification of truffles. Rapid Communications in Mass Spectrometry, 2365-2370. https://doi.org/10.1002/rcm.2031

8. Konieczny, A., \& Kowalska, I. (2017). Arbuscular mycorrhiza partner in communication. Acta Scientiarum Polonorum, Hortorum Cultus, 16(4), 73-78. https://doi.org/10.24326/asphc.2017.4.8

9. Liu, B., Fischer, C. R., Bonet, J. A., et. al. (2016). Shifts in soil fungal communities in Tuber melanosporum plantations over a 20 -year transition from agriculture fields to oak woodlands. $\mathrm{Fo}$ rest Systems, eSC05. https://doi.org/10.5424/fs/2016251-08353

10. Liu, Q. N., Liu, R. S., Wang, Y. H., et. al. (2009). Fed-batch fermentation of Tuber melanosporum for the hyperproduction of mycelia and bioactive Tuber polysaccharides. Bioresour Technol, 3644-3649. https://doi.org/10.1016/j.biortech.2009.02.037

11. Naheeda, Begum, Cheng, Qin, Muhammad, Abass, Ahanger, et. al. (2019). Role of Arbuscular Mycorrhizal Fungi in Plant Growth Regulation. Implications in Abiotic Stress Tolerance. Front. Plant Sci. https://doi.org/10.3389/fpls.2019.01068

12. Nardinia, A., Salleo, S., Tyree, M. T., Vertovec, M. (2000). Influence of the ectomycorrhizas formed by Tuber melanosporum Vitt. on hydraulic conductance and water relations of Quercus ilex L. seedlings (in German). Annals of Forest Science, 305-312. https://doi.org/10.1051/forest:2000121

13. Oliferchuk, V. P., \& Fedorovych, D. V. (2019). Aplication of mycorrhizal fungus Tuber melanosporum to stimulate the growth and development of soybean and spring barley. Faktori eksperementalnoi evoliutcii organizmiv, 133-138.

14. Olivera, Á., Bonet, J. A., Palacio, L., et. al. (2014). Weed control modifies Tuber melanosporum mycelial expansion in young oak plantations. Annals of Forest Science, 495-504. https://doi.org/10.1007/s13595-014-0360-X

15. Pinkas, Y., Maimon, M., Shabi, E., Elisha,Y., Shmulewich, S., Freeman, S. (2000). Inoculation, isolation and identification of Tuber melanosporum from old and new oak hosts in Israel. Mycological Research, 104(4), 472-477.

16. Parks, D. H., Tyson, G. W., \& Hugenholtz, P. (2014). STAMP: statistical analysis of taxonomic and functional profiles. Bioinformatics, 30, 3123-3124. https://doi.org/10.1093/bioinformatics/btu494

17. Patkowska, E., Jamiołkowska, A., \& Błażewicz-Woźniak, M. (2018). Antagonistic activity of selected fungi of the soil environment of carrot. Plant Soil Environ, 64(2), 58-63. https://doi.org/10.17221/792/2017-PSE 
18. Solti, Á., Tamaskó, L., Lenk, S., et. al. (2011). Detection of the vitalization effect of Tuber mycorrhiza on sessile oak by the recently-innovated FMM chlorophyll fluorometer. Acta Biologica Szegediensis, 147-149.

19. Tacon, F., Rubini, A., Murat, C., et. al. (2016). Certainties and uncertainties about the life cycle of the Périgord black truffle (Tuber melanosporum Vittad). Annals of Forest Science, 105-117. https://doi.org/10.1007/s13595-015-0461-1

20. Xin - Xin, Wang., Ellis, Hoffland, et. al. (2020). Arbuscular mycorrhizal symbiosis increases phosphorus uptake and producti- vity of mixtures of maize varieties compared to monocultures. Jornal of Epplied EcologyFirst published. https://doi.org/10.1111/1365-2664.13739

21. Zabkiewicz, A., Myga-Nowak, M., Bandurska, K., et. al. (2014). The application of PCR reaction for identification of MHB bacteria species. Archives of Environmental Protection, 40(2), 115122. https://doi.org/10.2478/aep-2014-0020

22. Zviagintceva, D. G. (1991). Metody pochvennoi mikrobiologii $i$ biokhimii. Moscow: Izd-vo Mosk. un-ta, 304 p. [In Russian].

V. P. Oliferchuk1, D. V. Fedorovych ${ }^{2}$

${ }^{1}$ Ukrainian National Forestry University, Lviv, Ukraine ${ }^{2}$ Institute of Cell Biology of National Academy of Sciences of Ukraine, Lviv, Ukraine

\section{INFLUENCE OF TUBER MELANOSPORUM MYCORRHYSTIC MUSHROOMS ON THE BIODIVERSITY RHISOSPHERE MICROMYCETES AND GROWTH AND PRODUCTIVITY OF HAZELNUT}

The presence of mycorrhiza is the reason for the efficient process of carbon deposition in the ecosystem. Different methods of mycorrhization contribute to the effective growth and productivity of plants. The effect of Tuber melanosporum IMB F-100106 in Mikovital composition on the growth, development and productivity of Masterpiece hazelnuts was studied. The influence of different methods of mycorrhizal preparation such as root soaking, drip irrigation and fertilization on the growth and development of hazelnuts has been studied. The results of the research have revealed that the diameter of the root neck increased by $10.2 \%$, the number of main roots increased by $12.2 \%$ and the length of the root system increased by $13.9 \%$. There was also an increase in the total number of leaves by $14.0 \%$, the length of annual growth - by $14.4 \%$ and the height of seedlings - by $12.9 \%$. Root fertilization with $2-5 \%$ solutions of the drug provided an increase in yield levels of hazelnuts to 21.7-22.4 c/ha with a yield increase of $10.2-13.7 \%$. Important indicators for nut plants are the chemical composition of the fruit and their tasting evaluation. Root feeding with $2-5 \%$ solution of the drug did not increase their fat content by $1.5-2.7 \%$, and also led to an increase in kernel yield by $6.0-6.9 \%$. Tasting evaluation of fruits increased by 0.3-0.4 points. Mycological analysis of 150 soil samples of hazelnut rhizosphere and virgin land soil was performed. 475 isolates of micromycetes belonging to 124 species of microscopic fungi were isolated. 48 species of microscopic fungi of different taxonomic groups, which were most often found in the studied soils, are presented. The mycoflora of the rhizosphere of mycorrhizal and non-mycorrhizal hazelnuts was found to differ sharply in species composition. Indices of species diversity of micromycetes indicate that the most diverse species composition of mycobiota is characteristic of the rhizosphere of mycorrhizal hazelnuts. A characteristic feature of the micromycetic composition of the rhizosphere of mycorrhizal hazelnuts is a decrease in the number and species diversity of pathogens. The capacity of the hazelnut garden ecosystem, the ability to create living conditions for populations of different species, in particular soil micromycetes, is analyzed. The role of regenerative land use technology, which we successfully implement in Ukraine at the level of forests, small and medium farms, and holdings, has been determined as well. It can become the basis of the Food Sovereignty of our country and will allow Ukraine to develop according to its unique plan, i.e. to preserve a healthy environment for future generations and to provide the population with quality organic food.

Keywords: carbon deposition; mycorrhization; heterotrophic plant nutrition; regenerative land use technology. 